\title{
THE INFLUENCE OF SERVICE QUALITY AND PRICE TOWARD TRUST AND ITS IMPACT ON CUSTOMER LOYALTY OF LOW COST CARRIER INDONESIA
}

\author{
Mohamad Rizan \\ Faculty of Economic State University of Jakarta \\ e-mail: dr_rizan@yahoo.com \\ Restu Setyaningsih \\ Faculty of Economic State University of Jakarta \\ e-mail: restutuk22@gmail.com \\ Basrah Saidani \\ Faculty of Economic State University of Jakarta \\ e-mail: basrah_sp@yahoo.com
}

\begin{abstract}
This study was conducted to determine the descriptive and empirical impact of service quality and price on customer loyalty by the trust as a mediator variable. The object of this research was 200 respondents who have ever used the service of Indonesia AirAsia at least two times in Jakarta. Methods of data collection using survey methods. Data analysis using SPSS version 22 and SEM (Structural Equation Model) of a statistical package LISREL 8.7 to process and analyze the research data. The results of descriptive test explained that the service quality and price provided is good according to the customer, so that the customer is believe and tend to be a loyal customer of Indonesia AirAsia. The hypothesis test shows; (1) price has positive and significant effect on customer loyalty, but positive effect is insignificant on service quality to customer loyalty; (2) service quality and price has positive and significant effect on trust; (3) trust has positive and significant effect on customer loyalty; (4) service quality and price has positive and significant effect on customer loyalty through trust as mediating variable.
\end{abstract}

Keywords: service quality, price, trust, customer loyalty 


\section{PENDAHULUAN}

Transportasi adalah hal yang tidak bisa terlepas dari kebutuhan manusia dan menjadi salah satu hal terpenting dalam mendukung kegiatan dan mobilitas manusia di segala aktifitas yang sesuai dengan pengertian trasnportasi yaitu pemindahan manusia atau barang dari satu tempat ke tempat lain dengan menggunakan sebuah wahana yang digerakan oleh manusia atau mesin, transportasi digunakan untuk memudahkan manusia dalam melakukan aktivitas sehari-hari (Ismayati, 2010:126). Transportasi dapat diklarifikasikan dari sudut jalan, atau permukaan jalan yang digunakan, alat angkutan yang dipakai dan tenaga gerak yang digunakan menjadi tiga jenis yaitu transportasi darat, air dan udara (Kadir, 2006: 123), yang mana pemilihannya disesuaikan dengan kebutuhan. Salah satu pilihan moda transportasi yang dapat menjangkau jarak yang jauh dengan efisiensi waktu adalah transportasi udara.

Tranportasi udara merupakan salah satu komponen terpenting dalam sistem transportasi dunia, bukan hanya menyediakan sarana utama perjalanan jarak jauh di dunia, tetapi memiliki dampak ekonomi terhadap perekonomian global dan nasional substansial (Nissalke, n.d). Perkembangan penggunaan transportasi udara dari tahun ke tahun sedikit demi sedikit meningkat. Diawal kemunculan pesawat terbang sebagai trasportasi udara merupakan jenis trasportasi kalangan atas karena biaya yang dikenakan relatif mahal, namun dalam perkembangannya banyak perusahaan penerbangan yang melebarkan segmentasinya untuk membuka penerbangan berbiaya rendah untuk tetap bertahan maupun meraup pasar yang kosong di industri penerbangan dan akhirnya muncul Low Cost Carriers yaitu sebuah maskapai udara yang memiliki struktur biaya relatif rendah dibandingkan dengan maskapai lain yang sebanding dan menawarkan tarif dan biaya rendah, seperti maskapai penerbangan independen, divisi atau anak perusahaan dari maskapai jaringan utama atau, dalam beberapa kasus, ex-charter grup maskapai penerbangan (ICAO, 2009). Penerbangan jenis ini mampu menawarkan harga tiket yang terjangkau dengan mengurangi beberapa layanan umum bagi penumpang pesawat seperti layanan catering dan meminimalisasi reservasi sehingga berakibat pada penurunan biaya. Perkembangan Low Cost Carriers di Indonesia membuat persaingan dalam bisnis penerbangan terus meningkat, yang mana pebenerbangan berbiaya rendah sangat menarik minat menarik minat masyarakat untuk menggunakan transportasi udara yaitu pesawat terbang. AirAsia, Citilink, dan Lion Air merupakan beberapa contoh penerbangan yang sering menjadi pilihan konsumen dalam kategori Low Cost Carriers di Indonesia. 
Salah satu penerbangan Low Cost Carriers yang sudah mempunyai nama besar baik di dalam dan luar negeri adalah AirAsia, perusahaan penerbangan asal Malaysia yang didirikan oleh Tony Fernandes pada tahun 2001 ini semakin berkembang dan akhirnya masuk ke Indonesia yang didirikan pada tanggal 8 Desember 2004, melalui kerjasama ventura antara AirAsia International Ltd. dengan PT. Awair Internasional (AirAsia, 2016). Penerbangan AirAsia menetapkan harga penerbangan yang lebih murah dibanding dengan perusahaan penerbangan lain dan memberikan banyak penawaran spesial dan promo harga yang sangat murah. Adapun perbandingan harga tiket penerbangan maskapai bertarif rendah di Indonesia pada pemesanan 19 mei 2016 untuk penerbangan 11 mei 2016 dapat dilihat di Tabel I.2

Tabel I. 1

Daftar Harga Tiket Penerbangan LCC

\begin{tabular}{|c|c|c|c|}
\hline \multirow[t]{2}{*}{ Tujuan } & Indonesia AirAsia & Citilink & Lion Air \\
\hline & Jakarta (CGK) & Jakarta (CGK) & Jakarta (CGK) \\
\hline Bali (DPS) & 465.000 & 525.000 & 769.000 \\
\hline Surabaya (SUB) & 429.000 & 351.000 & 638.000 \\
\hline Yogyakarta (JOG) & 319.000 & 396.000 & 494.000 \\
\hline Singapura & 459.000 & - & 670.000 \\
\hline Kuala lumpur & 399.000 & - & 575.000 \\
\hline Bangkok & 899.000 & - & 1.455 .300 \\
\hline
\end{tabular}

Sumber: Website masing-masing maskapai

Keunggulan dalam memberikan harga murah dan promo-promo yang menarik baik untuk rute domestik maupun internasional didukung dengan keberhasilan AirAsia memenangkan penghargaan ditahun 2014 sampai 2016 untuk World's Best Low-Cost Airlines dari SKAYTRAX tujuh kali berturut-turut (SKYTRAX, 2016). Hal-hal tersebutlah yang menarik minat dan kepercayaan masyarakat untuk memilih AirAsia dan menggunakan penerbangan AirAsia terus menerus, terbukti dengan peningkatan posisi Indonesia AirAsia dalam kategori transportasi Top Brand Indonesia. pada tahun 2012 AirAsia berada di posisi ketiga dan AirAsia mengalami peningkatan presentase di tahuntahun berikutnya dan puncaknya AirAsia berhasil meraih penghargaan Top Brand Indonesia dalam kategori transportasi setelah Garuda Indonesia di peringkat pertama dan Lion Air yang merupakan Low Cost Carier di peringkat kedua di tahun 2014 (Top Brand Award, 2016). 
Tabel 1.

Top Brand Award Kategori Penerbangan tahun 2012-2014

\begin{tabular}{|c|c|c|c|c|c|c|c|c|}
\hline \multicolumn{3}{|c|}{2012} & \multicolumn{3}{|c|}{2013} & \multicolumn{3}{|c|}{2014} \\
\hline Merek & TBI & TOP & Merek & TBI & TOP & Merek & TBI & TOP \\
\hline Garuda Indonesia & $43,6 \%$ & TOP & Garuda Indonesia & $41,2 \%$ & TOP & Garuda Indonesia & $39,6 \%$ & TOP \\
\hline Lion Air & $25,9 \%$ & TOP & Lion Air & $30,8 \%$ & TOP & Lion Air & $32,3 \%$ & TOP \\
\hline AirAsia & $7,8 \%$ & & AirAsia & $9,9 \%$ & & AirAsia & $10,8 \%$ & TOP \\
\hline Batavia Air & $7,1 \%$ & & Sriwijaya Air & $5,8 \%$ & & Sriwijaya Air & $4,0 \%$ & \\
\hline Sriwijaya Air & $4,4 \%$ & & Batavia Air & $5,8 \%$ & & Citilink & $2,7 \%$ & \\
\hline Merpati & $3,8 \%$ & & Merpati & $2,6 \%$ & & Merpati & $2,5 \%$ & \\
\hline Mandala & $1,6 \%$ & & $\begin{array}{l}\text { Singapore } \\
\text { Airlines }\end{array}$ & $1,1 \%$ & & & & \\
\hline Emirates Airlines & $1,0 \%$ & & Citilink & $0,8 \%$ & & & & \\
\hline
\end{tabular}

Namun kesuksesan AirAsia mendapatkan penghargaan Top Brand Indonesia dalam kategori transportasi udara di tahun 2014 tidak bertahan lama. Tragedi jatuhnya Pesawat AirAsia QZ8501 Surabaya - Singapore di Selat Karimata pada tanggal 28 desember 2014 setelah lepas kontak dari Bandara Djuanda Surabanya menjadi coretan besar dalam sejarah penerbangan Indonesia AirAsia yang menelan korban sebanyak 162 korban yang terdiri dari dua pilot, empat awak kabin, dan 156 penumpang, termasuk seorang engineer dan tidak satupun berhasil ditemukan dalam keadaan selamat (MetroTV News, 2015).

Penyebab jatuhnya QZ8501 yang dipiloti Kapten Irianto diawal jatuhnya diperkirakan oleh Badan Meteorologi Klimatologi dan Geofisika (BMKG) Pangkal Pinang Provinsi Kepulauan Bangka Belitung penyebabnya adalah kondisi cuaca yang buruk dan adanya awan comulonimbus (Cb) (Tempo, 2014), didukung lagi oleh penyataan mantan Pilot Datuk Jalil Mat Dom jika badai di wilayah tersebut intens dan membahayakan pilot bisa merubah jalur penerbangan (Okezone, 2014). Tidak berhenti disitu, masalah lain muncul ketika ditelurusi lebih lanjut manajemen Indonesia AirAsia seperti penerbangan AirAsia Surabaya - Singapura untuk tanggal 28 desember 2014 tidak memiliki izin terbang (Kompas, 2015), dimana seharusnya AirAsia hanya memperoleh izin terbang pada hari senin, selasa, jumat dan sabtu. Namun, realisasinya senin, selasa, jumat dan minggu yang dibenarkan oleh Kepala Otoritas Bandara Wilayah III Bandara Juanda Surabaya Praminto Hadi, dan permasalahan izin penerbangan AirAsia lainnya pun setelah itu terus bermunculan di daerah lain.

Setelah hampir satu tahun tragedi AirAsia QZ8501 penyebab sebenarnya jatuhnya maskapai penerbangan ini akhirnya diketahui, Komite Nasional Keselamatan Transportasi (KNKT) merilis hasil investigasi terhadap kotak hitam milik pesawat 
AirAsia QZ8501 yang berhasil ditemukan. Menurut KNKT, terdapat sejumlah faktor yang menjadi penyebab kecelakaan, Investigator KNKT Nurcahyo Utomo menyatakan dari awal QZ8501 terbang sudah mengalami beberapa kali gangguan di 30 menit awal dan ada lima faktor yang membuat QZ8501 terjatuh yang mana merupakan kesalahan dalam pengoperasian sistem (Tribun News, 2015).

Pasca tragedi QZ8501 di akhir tahun 2014 tidak hanya membuat keluarga korban yang terkejut namun membuat konsumen AirAsia lainnya dan seluruh masyarakat Indonesia juga terkejut dan mempertanyakan harga murah yang diberikan AirAsia apakah sepadan dengan pelayanan yang diberikan serta mempentingkan keselamatan penumpangnya ataukah tidak, walaupun AirAsia sudah bertanggung jawab atas tragedi QZ8501 dengan baik namun ketakukan di masyarakat akan penerbangan AirAsia masih ada. Penjualan tiket yang menurun pun sudah diakui oleh Presiden Direktur Indonesia AirAsia Sunu Widyatmoko pasca tragedi tersebut (Tribun News , 2015).

Penghargaan Top Brand Indonesia yang AirAsia dapatkan pada tahun 2014 pun tidak bisa dipertahankan lagi pada tahun-tahun berikutnya yaitu tahun 2015 dan 2016 (Top Brand Award, 2016). Posisi AirAsia dalam kategori transportasi penerbangan menunjukan penurunan presentase dan posisi secara perlahan-lahan, posisi yang telah Indonesia AirAsia capai sebelumnya harus digantikan oleh maskapai penerbangan Low Cost Carriers lain, walaupun disisi lain AirAsia secara Internasional masih mampu mempertahankan World's Best Low-Cost Airlines dari SKAYTRAX namun tidak di Indonesia, yang mana tidak terlalu mempengaruhi presepsi konsumen Indonesia.

Tabel 2.

Tabel Top Brand Award Kategori Penerbangan tahun 2014-2016

\begin{tabular}{|c|c|c|c|c|c|c|c|c|}
\hline \multicolumn{3}{|c|}{2014} & \multicolumn{3}{|c|}{2015} & \multicolumn{3}{|c|}{2016} \\
\hline Merek & TBI & TOP & Merek & TBI & TOP & Merek & TBI & TOP \\
\hline $\begin{array}{l}\text { Garuda } \\
\text { Indonesia }\end{array}$ & $39,6 \%$ & TOP & Garuda Indonesia & $40,0 \%$ & TOP & Garuda Indonesia & $41,0 \%$ & TOP \\
\hline Lion Air & $32,3 \%$ & TOP & Lion Air & $35,1 \%$ & TOP & Lion Air & $30,5 \%$ & TOP \\
\hline AirAsia & $10,8 \%$ & TOP & AirAsia & $8,7 \%$ & & Citilink & $8,9 \%$ & \\
\hline Sriwijaya Air & $4,0 \%$ & & Citilink & $4.4 \%$ & & AirAsia & $7,7 \%$ & \\
\hline Citilink & $2,7 \%$ & & Sriwijaya Air & $4,4 \%$ & & Sriwijaya Air & $3,2 \%$ & \\
\hline Merpati & $2,5 \%$ & & & & & Batik Air & $3,2 \%$ & \\
\hline
\end{tabular}

Sumber : Top Brand Award Survei

Dari fenomena tersebut diketahui jika AirAsia memiliki permasalahan dari segi pelayanan penerbangan bertarif murah, banyak yang mempertanyakan harga murah yang diberikan apakah menjamin keselamatan penumpang apalagi faktor internalah yang menjadi asal mula tragedi AirAsia ini, yang mana pelayanan yang diberikan berbeda 
dengan apa yang konsumen harapkan, yang mana safety, on time performance, dan convenience of schedules dapat dimasukan diantara faktor-faktor terpenting dalam menentukan Low Cost Carriers yang lebih baik (Atalik dan Ozel, 287). Dilihat dari turunnya presentase dan posisi AirAsia dalam Top Brand tahun-ketahun, serta penurunan penjualan bisa dipegaruhi oleh faktor kepercayaan konsumen, padahal jumlah pemakai maskapai penerbangan dari tahun-ketahun terus meningkat, yang mana hal itu menunjukan jika pelayanan dan harga murah yang diberikan tidak menjamin kepercayaan konsumen untuk memiliki loyalitas terhadap AirAsia untuk memperoleh pembelian jangka panjang dari konsumen di masa selanjutnya. Sehingga dari fenomena turunnya peringkat Indonesia AirAsia pada survei Top Brand Indonesia kategori transportasi penerbangan yang mana tidak bisa mempertahankan kemenangan penghargaannya pada tahun 2014 muncul pertanyaan apakah terdapat hubungan antara kualitas pelayanan dan harga terhadap kepercayaan serta dampaknya pada loyalitas pelanggan.

\section{Perumusan Masalah}

1. Bagaimana analisis deskriptif kualitas pelayanan, harga, kepercayaan dan loyalitas pelanggan maskapai penerbangan bertarif rendah AirAsia?

2. Apakah kualitas pelayanan berpengaruh terhadap kepercayaan maskapai penerbangan bertarif rendah AirAsia?

3. Apakah harga berpengaruh terhadap kepercayaan maskapai penerbangan bertarif rendah AirAsia?

4. Apakah kualitas pelayanan berpengaruh terhadap loyalitas pelanggan maskapai penerbangan bertarif rendah AirAsia?

5. Apakah harga berpengaruh terhadap loyalitas pelanggan maskapai penerbangan bertarif rendah AirAsia?

6. Apakah kepercayaan berpengaruh terhadap loyalitas pelanggan maskapai penerbangan bertarif rendah AirAsia?

7. Apakah kualitas pelayanan berpengaruh terhadap loyalitas pelanggan melalui kepercayaan sebagai variabel mediasi maskapai penerbangan bertarif rendah AirAsia?

8. Apakah harga berpengaruh terhadap loyalitas pelanggan melalui kepercayaan sebagai variabel mediasi maskapai penerbangan bertarif rendah AirAsia? 


\section{Tujuan Penelitian}

1. Untuk menganalisis secara deskriptif kualitas pelayanan, harga, kepercayaan dan loyalitas pelanggan maskapai penerbangan bertarif rendah AirAsia.

2. Untuk mengetahui pengaruh kualitas pelayanan terhadap kepercayaan maskapai penerbangan bertarif rendah AirAsia.

3. Untuk mengetahui pengaruh harga terhadap kepercayaan maskapai penerbangan bertarif rendah AirAsia.

4. Untuk mengetahui pengaruh kualitas pelayanan terhadap loyalitas pelanggan maskapai penerbangan bertarif rendah AirAsia.

5. Untuk mengetahui pengaruh harga terhadap loyalitas pelanggan maskapai penerbangan bertarif rendah AirAsia.

6. Untuk mengetahui pengaruh kepercayaan terhadap loyalitas pelanggan maskapai penerbangan bertarif rendah AirAsia.

7. Untuk mengetahui pengaruh kualitas pelayanan terhadap loyalitas pelanggan melalui kepercayaan sebagai variabel mediasi maskapai penerbangan bertarif rendah AirAsia.

8. Untuk mengetahui pengaruh harga terhadap loyalitas pelanggan melalui kepercayaan sebagai variabel mediasi maskapai penerbangan bertarif rendah AirAsia.

\section{KAJIAN TEORI}

\section{Loyalitas Pelanggan}

Menurut Oliver (Prasetio dan Keni, 2014:307) loyalitas pelanggan adalah komitmen yang dipegang untuk membeli kembali atau repatronize produk atau layanan yang lebih disukai secara konsisten di masa depan, sehingga menyebabkan pembelian merek yang sama atau set merek yang sama berulangulang, meskipun pengaruh situasional dan upaya pemasaran dapat berpotensi menyebabkan perilaku berpaling. Sedangkan menurut Cronin dan Taylor (Zangmo et. al., 2014:67) loyalitas pelanggan adalah sikap komponen yang mewakili gagasan pelanggan seperti niat pembelian kembali atau membeli produk atau layanan tambahan dari perusahaan yang sama, kesediaan untuk 
merekomendasikan perusahaan kepada orang lain dan menunjukkan komitmen mereka kepada perusahaan dengan memamerkan resistensi untuk beralih ke pesaing lain.

Berdasarkan definisi yang telah dijabarkan dapat disimpulkan bahwa loyalitas pelanggan adalah komitmen yang dipegang oleh para pembeli untuk membeli kembali produk atau layanan secara konsisten di masa depan meskipun terpengaruh dengan situasi dan upaya pemasaran yang menyebabkan potensi untuk berpindah. Untuk mengukur loyalitas menurut Jones dan Taylor (Rai dan Srivastava, 2012:63) terdapat tiga dimensi yaitu Behavioural Loyalty, Attitudinal Loyalty, dan Cognitive Loyalty.

\section{Kepercayaan}

Definisi kepercayaan adalah dasar untuk menjaga hubungan jangka panjang dengan pelanggan, dan membantu untuk meningkatkan kemungkinan bahwa pelanggan akan tetap loyal (Kanuk dan Schiffman,2010:3).

Menurut Sirdeshmukh et al. (Prasetio dan Keni, 2014:306) kepercayaan merupakan harapan yang dimiliki konsumen bahwa penyedia jasa dapat diandalkan untuk memenuhi janjinya

Dari beberapa penjelasan kepercayaan oleh para ahli yang telah dijelaskan dapat disimpulkan bahwa kepercayaan adalah perasaan dimana pelanggan merasa bahwa penyedia layanan dapat diandalkan dan dapat dipercaya untuk memenuhi janjinya sesuai dengan harapan pelanggan. Hasil penelitian sebelumnya oleh Pi dan Huang menunjukan jika kepercayaan memiliki pengaruh positif signifikan terhadap loyalitas (Pi dan Huang, 2014:4413). Menurut Morgan dan Hunt terdapat tiga dimensi untuk mengukur customer trust yaitu capabilities (ability), goodness (benevolence), dan integrity (Hasniaty, 2015:182).

\section{Harga}

Harga adalah sejumlah uang yang ditagihkan atas suatu produk atau jasa, atau jumlah dari nilai yang ditukarkan para pelanggan untuk memperoleh manfaat dari memiliki atau menggunakan produk atau jasa (Kotler dan Armstrong, 2014:291). 
Dari sudut pandang konsumen menurut Kim et al. (Haghighi et al., 2012:5042) harga adalah apa yang pelanggan bayarkan atau berikan yang diberlakukan untuk produk atau jasa. Kewajaran harga adalah sebuah faktor psikologi yang memiliki peran penting dalam reaksi pelanggan untuk membayar harga.

Berdasarkan definisi para ahli dapat disimpulkan jika harga adalah sejumlah uang yang pelanggan bayarkan untuk mendapatkan produk atau jasa sehingga pelanggan dapat memperoleh manfaatnya. Dalam penerbangan harga atau tarif merupakan biaya yang dikenakan kepada calon penumpang untuk mendapatkan jasa penerbangan. Menurut Assauri terdapat tiga dimensi untuk mengukur harga, yaitu tingkat harga, potongan harga, dan cara pembayaran (Sitorus, 2012:14-15).

\section{Kualitas Pelayanan}

Kualitas layanan merujuk terhadap ekspektasi dan pelayanan yang dirasa dari penawaran sebuah jasa, dan memiliki dampak besar dalam daya saing sebuah perusahaan (Boone dan Kurtz, 2015:396).

Menurut Zeithaml et. al., (Kalaiarasan et. al., 2015:1130) kualitas pelayanan adalah sebuah subjek penting dalam kedua sektor umum dan swasta, dalam industri bisnis dan jasa. Sejauh mana sebuah pelayanan memenuhi atau melebihi kebutuhan dan ekspektasi pelanggan.

Berdasarkan definisi yang telah dijelaskan maka kualitas pelayanan adalah ukuran seberapa bagusnya tingkat pelayanan yang penyedia jasa berikan sesuai dan memenuhi ekspektasi dan pelayanan akan kebutuhan pelanggan. Yang mana kualitas pelayanan sebagai ukuran ini merupakan hal penting bagi perusahaan penyedia jasa untuk bersaing dengan penyedia jasa lainnya.

Dalam penelitian terdahulu menunjukan jika service quality dan price mempegaruhi secara signifikan terhadap customer loyalty (Amiruddin, 2013:3637). Begitu pula penelitian Hasniaty dengan jurnal penerbangannya menunjukan jika service quality dan price memiliki pengaruh terhadap trust (Hsniaty, 2015:184). Menurut Zeithaml et.al., (Lovelock dan Wirtz, 2011:37) service quality dapat diukur melalui lima dimensi yaitu; Tangibles (bukti fisik), 
Reliability (kehanadalan), Responsiveness (daya tanggap), Assurance (jaminan), Empathy (empati).

\section{Kerangka Pemikiran}

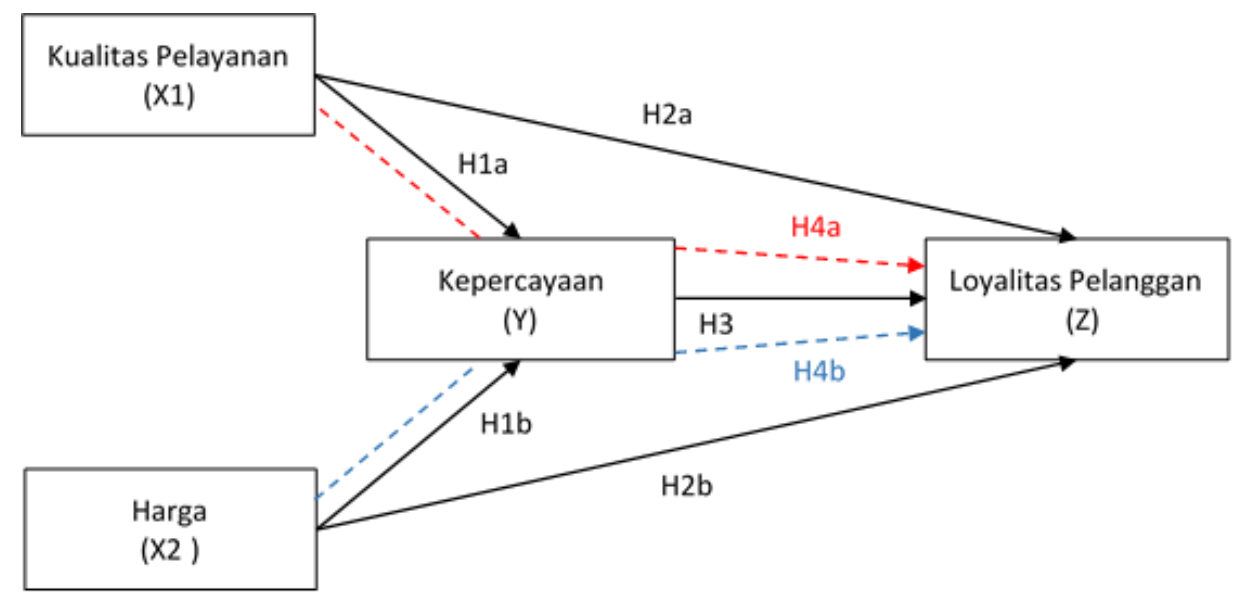

Gambar 1. Kerangka Pemikiran

Sumber: Data diolah Penulis (2016)

Berdasarkan kerangka model penelitian pada gambar di atas maka untuk tujuan explanatory dibuat hipotesis yang sesuai, adapun hipotesisnya sebagai berikut:

1. H1a : Kualitas pelayanan berpengaruh positif dan signifikan terhadap kepercayaan maskapai penerbangan bertarif rendah AirAsia.

H1b : Harga berpengaruh positif dan signifikan terhadap kepercayaan pada maskapai penerbangan bertarif rendah AirAsia.

2. H2a : Kualitas pelayanan berpengaruh positif dan signifikan terhadap loyalitas pelanggan maskapai penerbangan bertarif rendah AirAsia.

$\mathrm{H} 2 \mathrm{~b}$ : Harga berpengaruh positif dan signifikan terhadap loyalitas pelanggan maskapai penerbangan bertarif rendah AirAsia.

3. H3 : Kepercayaan berpengaruh positif dan signifikan terhadap loyalitas pelanggan maskapai penerbangan bertarif rendah AirAsia.

4. H4a : Kualitas pelayanan berpengaruh positif dan signifikan terhadap loyalitas pelanggan melalui kepercayaan sebagai variabel mediasi maskapai penerbangan bertarif rendah AirAsia. 
H4b : Harga berpengaruh positif dan signifikan terhadap loyalitas pelanggan melalui kepercayaan sebagai variabel mediasi maskapai penerbangan bertarif rendah AirAsia.

\section{METODE PENELITIAN}

Metode yang digunakan dalam penelitian ini adalah penelitian kuantitatif yaitu metodologi penelitian yang berusaha untuk mengukur data dan biasanya, berlaku beberapa bentuk analisis statistik (Malhotra, 2010:139). Desain penelitian ini adalah explanatory dengan jenis penelitian deskriptif dan kausal, yaitu peneliti akan melakukan pengujian terhadap hipotesis-hipotesis dan menguji pengaruh dari variabel independen terhadap variabel dependen yaitu kualitas pelayanan, kepuasan pelanggan dan loyalitas pelanggan. Metode penelitian adalah dengan metode survei menggunakan kuesioner terstruktur, yang pertanyaanya telah dipersiapkan dan kuesioner akan diberikan secara langsung kepada responden.

Populasi dalam penelitian ini adalah penumpang maskapai penerbangan Indonesia AirAsia di Jakarta yang telah menggunakan jasa penerbangan Indonesia AirAsia minimal sebanyak 2 kali. Jenis populasi yang akan diteliti adalah populasi infinite yaitu objek dengan ukuran yang tidak terhingga.

Metode sampling yang digunakan dalam penelitian ini adalah purposive sampling yang mana peneliti dalam penelitian ini tidak mengetahui jumlah pasti penumpang maskapai penerbangan Indonesia AirAsia di Jakarta yang telah menggunakan jasa penerbangan tersebut minimal sebanyak 2 kali.

Menurut Hair et al. (Sanusi, 2011:175) ada beberapa saran yang dapat digunakan sebagai pedoman dalam menentukan ukuran sampel dalam analisis SEM salah satunya bahwa critical sample size untuk analisis menggunakan LISREL adalah 200 sampel, sehingga dalam penelitian ini menggunakan sebanyak 200 sampel.

Data dalam penelitian ini data yang digunakan untuk diolah adalah data primer yang dikumpulkan melalui penyebaran kuesioner untuk diisi oleh responden guna mendapatkan informasi mengenai variabel-variabel yang akan diteliti. Skala pengukuran yang digunakan pada penelitian ini adalah Skala likert. 
Menurut Malhotra (Sanusi, 2011:175) skala likert adalah skala dengan lima katagori respon dari "sangat tidak setuju" sampai "sangat setuju”, yang mana responden dibutuhkan untuk mengidentifikasi tingkat peresetujuan maupun ke tidak setujuan dari setiap pernyataan yang berhubungan dengan penelitian yang tertera di kuesioner (Malhotra, 2010:276). Dalam penelitian ini peneliti menggunakan skala likert dengan enam kategori respon guna mengurangi jawaban netral dari responden.

\section{UJI INSTRUMEN}

\section{Uji Validitas}

Uji validitas digunakan untuk mengetahui kelayakan butir-butir dalam suatu daftar pertanyaan dalam mendefinisikan suatu variabel. Uji validitas dilakukan untuk mengetahui valid atau tidaknya kuesioner yang digunakan untuk penelitian, jika terdapat butir pernyataan yang tidak valid maka diperlukan eliminasi. Dalam penelitian ini pengujian validitas dilakukan dengan menggunakan teknik korelasi Kaiser Meyer Olkin Measure of Sampling (KMO). Teknik ini adalah indeks perbandingan jarak antara koefisien korelasi dengan koefisian korelasi parsialnya. Jika jumlah kuadrat koefisien korelasi parsial di antara seluruh pasangan variabel bernilai kecil jika dibandingkan dengan jumlah kuadrat koefisien korelasi, maka akan menghasilkan nilai KMO mendekati 1. Nilai KMO dianggap mencukupi jika $\geq 0,5$. Adapun Hasil uji validitas pada penelitian ini yaitu:

Tabel 3.

Hasil Uji Validitas

\begin{tabular}{ccccc}
\hline Variabel & $\begin{array}{c}\text { Jumlah Item } \\
\text { Sebelum Diuji }\end{array}$ & $\begin{array}{c}\text { Jumlah Item } \\
\text { Tidak Valid }\end{array}$ & $\begin{array}{c}\text { Jumlah Item } \\
\text { Valid }\end{array}$ & Nilai KMO \\
\hline $\begin{array}{c}\text { Loyalitas } \\
\text { Pelanggan }\end{array}$ & 12 & 2 & 10 & 0,878 \\
\hline Kepercayaan & 10 & 0 & 10 & 0,950 \\
\hline Harga & 8 & 0 & 8 & 0,786 \\
\hline $\begin{array}{c}\text { Kualitas } \\
\text { Pelayanan }\end{array}$ & 22 & 0 & 22 & 0,958 \\
\hline Sumber: Data SPSS, 2016 & & & &
\end{tabular}

Berdasarkan hasil pada Tabel. 3 dapat disimpulkan bahwa instrumen variabel loyalitas pelanggan, kepercayaan, harga dan kualitas pelayanan dapat dikatakan 
valid karena telah memenuhi syarat nilai $\mathrm{KMO} \geq 0,5$ sehingga instrument dapat digunakan untuk pengujian lebih lanjut.

\section{Uji Reliabilitas}

Reliabilitas adalah alat untuk mengukur tingkat kehandalan suatu kuisioner yang mengambarkan indikator dari variabel. Suatu kuisioner dikatakan reliabel atau handal jika jawaban seseorang terhadap pertanyaan adalah konsisten atau stabil dari waktu ke waktu. Untuk pengujian dilakukan dengan membandingkan nilai cronbarch alpha dengan nilai koefisien reliabilitas minimal yaitu 0,6. Adapun hasil uji reliabilitas penelitian ini yaitu:

Tabel 4.

Hasil Uji Reliabilitas

\begin{tabular}{ccc}
\hline Variabel & Cronbach's Alpha & Keterangan \\
\hline Loyalitas Pelanggan & 0,930 & Reliabel \\
\hline Kepercayaan & 0,946 & Reliabel \\
\hline Harga & 0,845 & Reliabel \\
\hline Kualitas Pelayanan & 0,969 & Reliabel \\
\hline
\end{tabular}

Sumber: Data SPSS, 2016

Berdasarkan hasil pada Tabel 4. ditemukan bahwa nilai cronbarch alpha pada masing-masing variabel melebihi nilai 0,6 dengan demikian berdasarkan hasil tersebut dapat disimpulkan bahwa keempat variabel reliabel untuk digunakan dalam penelitian ini.

Uji Pengaruh Langsung dan Tidak Langsung

Tabel 5.

Pengaruh Langsung dan Tidak Langsung

\begin{tabular}{lcccc}
\hline Variabel Terikat & Variabel Bebas & $\begin{array}{c}\text { Pengaruh } \\
\text { Langsung }\end{array}$ & $\begin{array}{c}\text { Pengaruh } \\
\text { Tidak } \\
\text { Langsung }\end{array}$ \\
\hline Kepercayaan & $\leftarrow$ & Kualitas Pelayanan & 0.77 & - \\
\hline Kepercayaan & $\leftarrow$ & Harga & 0.24 & - \\
\hline Loyalitas Pelanggan & $\leftarrow$ & Kepercayaan & 0.45 & - \\
\hline Loyalitas Pelanggan & $\leftarrow$ & Kualitas Pelayanan & 0.57 & 0.35 \\
\hline Loyalitas Pelanggan & $\leftarrow$ & Harga & 0.45 & 0.11 \\
\hline Sumber: Data diolah Peneliti, 2016 & & &
\end{tabular}

Uji pengaruh langsung dan tidak langsung dilakukan untuk mengetahui adakah pengaruh langsung maupun tidak langsung variabel bebas yang mempengaruhi variabel terikat. Berdasarkan hasil analisis data dapat dilihat pengaruh langsung variabel kualitas pelayanan terhadap kepercayaan sebesar 
0.77, pengaruh langsung variabel harga terhadap kepercayaan sebesar 0.24 , pengaruh variabel kepercayaan terhadap loyalitas pelanggan sebesar 0.45 , pengaruh variabel kualitas pelayanan terhadap loyalitas pelanggan sebesar 0.57 , dan pengaruh variabel harga terhadap loyalitas pelanggan sebesar 0.45.

Pengaruh tidak langsung hanya dimiliki oleh variabel kualitas pelayanan dan harga terhadap loyalitas pelanggan, yaitu sebesar 0.35 untuk pengaruh tidak langsung variabel kualitas pelayanan terhadap loyalitas pelanggan dan sebesar 0.11 pengaruh tidak langsung variabel harga terhadap loyalitas pelanggan. Hal ini dikarenakan adanya variabel mediasi pada model penelitian antara kualitas pelayanan dan harga terhadap loyalitas pelanggan, yaitu variabel kepercayaan. Berdasarkan analisis dapat dilihat hasil dari uji pengaruh tidak langsung lebih kecil dibanding uji pengaruh langsung, dikarenakan efek pengaruh variabel kepercayaan yang terhadap variabel loyalitas pelanggan sehingga membuat angkanya menjadi lebih kecil.

\section{Uji Kesesuaian Model}

Tabel 7.

Full Model SEM

\begin{tabular}{cccc}
\hline Indeks & Cut of Value & Hasil & Evaluasi Model \\
\hline RSMEA & $\leq 0.08$ & 0.096 & Not Fitted \\
\hline NFI & $\geq 0.90$ & 0.95 & Fitted \\
\hline NNFI & $\geq 0.90$ & 0.97 & Fitted \\
\hline CFI & $\geq 0.95$ & 0.97 & Fitted \\
\hline CMIN/DF & $\leq 2.00$ & 2.75 & Not Fitted \\
\hline RMR & $\leq 0.05$ & 0.08 & Not Fitted \\
\hline
\end{tabular}

Sumber: Data diolah Peneliti, 2016

Berdasarkan tabel mengenai indeks goodness of fit untuk full model SEM dapat ditarik kesimpulan bahwa model belum memenuhi kriteria indeks goodness of fit. Maka dari itu modifikasi model dibutuhkan agar dapat menemukan model yang fit sesuai dengan kriteria goodness of fit. Setelah dilakukan modifikasi dan eliminasi indikator guna kesesuaian model yang baik maka didapatkan fit model SEM dengan nilai yang sudah sesuai dengan kriteria yang dibutuhkan.

Tabel 8.

Fit Model SEM

\begin{tabular}{cccc}
\hline Indeks & Cut of Value & Hasil & Evaluasi Model \\
\hline
\end{tabular}




\begin{tabular}{cccl}
\hline RSMEA & $\leq 0.08$ & 0.061 & Fitted \\
\hline NFI & $\geq 0.90$ & 0.97 & Fitted \\
\hline NNFI & $\geq 0.90$ & 0.99 & Fitted \\
\hline CFI & $\geq 0.95$ & 0.99 & Fitted \\
\hline CMIN/DF & $\leq 2.00$ & 1.78 & Fitted \\
\hline RMR & $\leq 0.05$ & 0.05 & Fitted
\end{tabular}

Sumber: Data diolah Peneliti, 2016

\section{Uji Hipotesis}

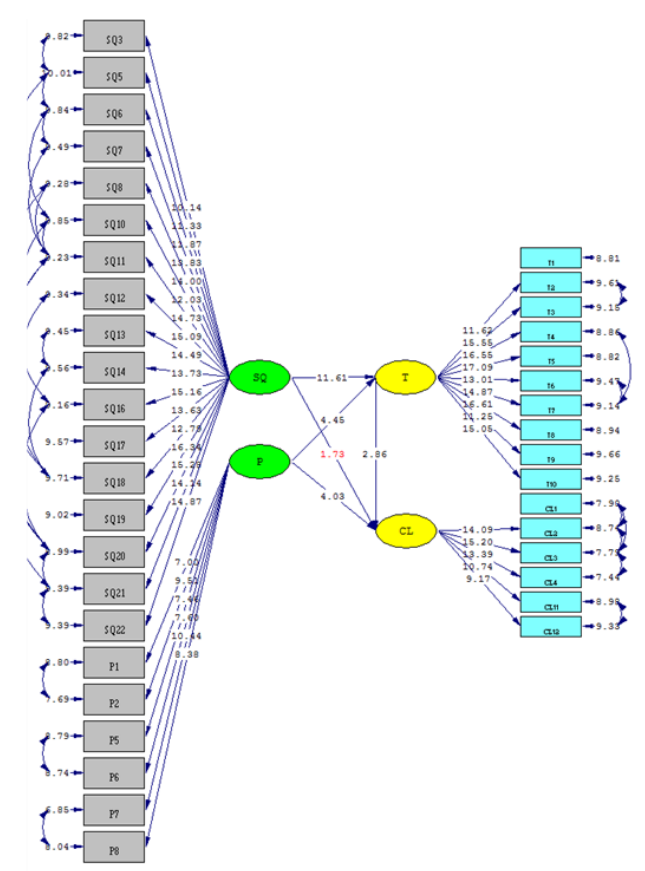

\section{Gambar 2. T-values SEM}

Sumber: Data diolah Penulis (2016)

Tabel 6.

Model Persamaan Struktural

\begin{tabular}{|c|c|c|c|c|c|c|}
\hline 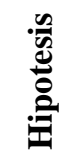 & $\begin{array}{l}\text { Variabel } \\
\text { Terikat }\end{array}$ & & $\begin{array}{c}\text { Variabel } \\
\text { Bebas }\end{array}$ & $\begin{array}{l}\text { Standardized } \\
\text { Total Effects }\end{array}$ & t-values & Intepretasi \\
\hline H1a & Kepercayaan & $\leftarrow$ & $\begin{array}{c}\text { Kualitas } \\
\text { Pelayanan }\end{array}$ & 0.77 & 11.61 & Signifikan \\
\hline H1b & Kepercayaan & $\leftarrow$ & Harga & 0.24 & 4.45 & Signifikan \\
\hline H2a & $\begin{array}{l}\text { Loyalitas } \\
\text { Pelanggan }\end{array}$ & $\leftarrow$ & $\begin{array}{l}\text { Kualitas } \\
\text { Pelayanan }\end{array}$ & 0.57 & 1.73 & Tidak Signifikan \\
\hline H2b & $\begin{array}{l}\text { Loyalitas } \\
\text { Pelanggan }\end{array}$ & $\leftarrow$ & Harga & 0.45 & 4.03 & Signifikan \\
\hline H3 & $\begin{array}{l}\text { Loyalitas } \\
\text { Pelanggan }\end{array}$ & $\leftarrow$ & Kepercayaan & 0.45 & 2.86 & Signifikan \\
\hline H4a & Loyalitas & Kepercayaan & Kualitas & 0.35 & 14.47 & Signifikan \\
\hline
\end{tabular}




\begin{tabular}{ccccccc}
\hline \multicolumn{3}{c}{ Pelanggan } & \multicolumn{5}{c}{ Pelayanan } \\
\hline H4b & $\begin{array}{c}\text { Loyalitas } \\
\text { Pelanggan }\end{array}$ & Kepercayaan & Harga & 0.11 & 7.31 & Signifikan \\
\hline
\end{tabular}

Sumber: Data diolah Peneliti, 2016

Model persamaan struktural dibutuhkan untuk menguji data apakah hipotesis yang dibuat diterima atau tidak. Untuk mengetahui hubungan antar variabel signifikan atau tidak dapat dilihat melalui nilai $t$-value dan untuk mengetahui seberapa besar pengaruhnya dapat dilihat melalui nilai standardized total effects.

Berdasarkan hasil model persamaan struktural yang telah dilakukan diketahui jika enam hubungan antar variabel memiliki nilai $t$-value $\geq 1.96$, yang artinya memiliki pengaruh antar variabel yang signifikan yaitu kualitas pelayanan terhadap kepercayaan (77\%), harga terhadap kepercayaan (24\%), loyalitas pelanggan (45\%), kepercayaan terhadap loyalitas pelanggan (45\%), kualitas pelayanan terhadap loyalitas melalui kepercayaan (35\%) dan harga terhadap loyalitas melalui kepercayaan (11\%), sedangkan satu hubungan memiliki nilai $t$ value $\leq 1.96$ yang berarti pengaruh antar variabel tersebut tidak signifikan yaitu hubungan kualitas pelayanan terhadap loyalitas pelanggan (57\%).

\section{KESIMPULAN DAN SARAN}

\section{Kesimpulan}

Setelah menganilisis data primer mengenai variabel-variabel penelitian dapat dilihat sebagai berikut:

1. Hipotesis 1a yang menyatakan variabel kualitas pelayanan terhadap kepercayaan berpengaruh positif dan signifikan diterima.

2. Hipotesis $1 \mathrm{~b}$ yang menyatakan variabel harga terhadap kepercayaan berpengaruh positif dan signifikan diterima.

3. Hipotesis 2 a yang menyatakan variabel kualitas pelayanan terhadap loyalitas pelanggan ditolak.

4. Hipotesis $2 \mathrm{~b}$ yang menyatakan variabel harga terhadap loyalitas pelanggan diterima.

5. Hipotesis 3 yang menyatakan variabel kepercayaan terhadap loyalitas pelanggan diterima. 
6. Hipotesis 4a yang menyatakan variabel kualitas pelayanan terhadap loyalitas pelanggan yang dimediasi kepercayaan diterima.

7. Hipotesis $4 \mathrm{~b}$ yang menyatakan variabel harga terhadap loyalitas pelanggan yang dimediasi kepercayaan diterima.

\section{Saran}

\section{Saran untuk AirAsia Indonesia}

a. AirAsia perlu meningkatkan kualitas pelayanan yang diberikan sesuai dengan standar yang berlaku baik kualitas pelayanan tangible (teknologi, badan pesawat, mesin, suasana, dst.) dan intangible (pelayanan dan penampilan staff dan kru, ketepatan waktu, dst.). dalam peningkatan kualitas untuk fisik AirAsia dapat memperbaharui, melakukan perawatan dan pengecekan secara berkala, meningkatkan sistem, untuk non fisik staff dan kru AirAsia perlu meningkatkan pemahamannya tentang AirAsia dan meningkatkan rasa peduli dan sensitifitasnya terhadap penumpang. Dengan kondisi yang baik AirAsia mampu memberikan pelayanan terbaik serta menepati janji yang diberikan kepada penumpang

b. AirAsia perlu meningkatkan strategi dan evaluasi terhadap pelayanan dan kinerja melalui tenaga pemasar guna mengetahui dan memenuhi apa yang diharapkan dari penumpang untuk perbaikan kedepan

c. AirAsia perlu meningkatkan kepercayaan konsmen salah satunya dengan meningkatkan dan memperhatikan sitem operasinya sehingga AirAsia mampu menyediakan penerbangan yang aman dan berkualitas di kelas penerbangan bertarif rendah dan membuat AirAsia mampu menarik minat calon pengguna baru serta mempertahankan pelanggannya dengan harga yang ditawarkan AirAsia

d. AirAsia memiliki peluang untuk menjadi maskapai penerbangan bertarif rendah nomor satu di Indonesia dan meraih kembali posisi TOP Brand Indonesia maka dari itu AirAsia perlu menarik hati konsumen

\section{Saran untuk Penelitian Selanjutnya}

a. Penelitian ini dapat dilakukan kembali dengan menggunakan variabel yang berbeda seperti; citra merek, kepuasan pelanggan, dan minat beli 
Jurnal Riset Manajemen Sains Indonesia (JRMSI) | Vol 7, No. 1, 2016

ulang sehingga dapat mengeksplorasi kemungkinan variabel lain yang dapat mempengaruhi loyalitas pelanggan dan juga sebagai variasi dalam penelitian.

b. Penelitian ini dapat dilakukan kembali dengan meneliti jenis penerbangan bertarif rendah lainnya seperti Lion Air dan Citilink sebagai pesaing di kelasnya.

c. Penelitian ini dapat dilakukan kembali dengan meneliti jenis penerbangan dengan pelayanan penuh (premium) seperti Garuda Indonesia, Batik Air, sdt.

d. Penelitian ini dapat dilakukan kembali dengan mengambil lokasi yang berbeda dan jumlah responden yang lebih luas sehingga akan mendapatkan tanggapan dan hasil yang berbeda pula. 


\section{DAFTAR PUSTAKA}

Abrar, A., 2015. Lima Penyebab Jatuhnya Air Asia QZ8501. [Online] Available at: http://news.metrotvnews.com/read/2015/12/02/196654/limapenyebab-jatuhnya-air-asia-qz8501

AirAsia, 2016. Corporate Profile. [Online]

Available at: http://www.airasia.com/id/id/about-us/corporate-profile.page

Aji, W., 2015. KNKT: Penyebab Jatuhnya AirAsia QZ8501 Bukan karena Faktor Cuaca,.

[Online]

Available at: http://www.tribunnews.com/nasional/2015/12/01/knktpenyebab-jatuhnya-airasia-qz8501-bukan-karena-faktor-cuaca

Amiruddin, N. H., 2013. Price, Service Quality And Customer Loyalty: A Case Of Air Asia. South East Asia Journal of Contemporary Business, Economics and Law, Vol. 2, Issue 1, June, pp. 36-37.

Atalık, Ö. \& Özel, E., n.d. Passenger Expectations And Factors Affecting Their Choice Of Low Cost Carriers: Pegasus Airlines. p. 287.

Boone, L. E. \& Kurtz, D. L., 2015. Contemporary Marketing. USA: Cengage Learing.

Grasindo, I., 2010. Pengatar Pariwisata. Jakarta: PT Gramedia Widisarana.

Haghighi, M., Dorosti, A., Rahnama, A. \& Hoseinpour, A., 2012. Evaluation of factors affecting customer loyalty in the restaurant industry. African Journal of Business Management, Vol. 6(14), p. 5042.

Hasniaty, 2015. Customer Perception On Products, Pricing, Service Quality, Towards Customer's Quality Relationships And Loyalty Of Domestic Airlines, Indonesia. International Journal of Scientific \& Technology Research, Vol.4, Issue 12, December, p. 182.

Internasional Civil Aviation (ICAO), 2009. Definition and Identification of LowCost Carriers, Montreal: ICAO. 
Kadir, A., 2006. Transportasi: Peran Dan Dampaknya Dalam Pertumbuhan Ekonomi Nasional. Jurnal Perencanaan \& Pengembangan Wilayah Wahana Hijau, Vol. 1 No. 3, April, p. 123.

Kalaiarasan, Appannan \& Doraisamy, 2015. A Study On Service Quality On Customer Satisfaction In Low Cost Airline Industries. Kalaiarasan, Appannan, dan Doraisamy,International Journal of Science, Environment, Technology, Vol.4 No.4, p. 1130.

Kotler, P. \& Gary, A., 2014. Principles of Marketing. 15th ed.. USA: Pearson Education Inc.

Kumar Rai, A. \& Srivastava, M., 2012. Customer Loyalty Attributes: A Perspective. NMIMS Management Review Volume XXII, October November, pp. 63-64.

Kuwado, F. J., 2015. Kecelakaan AirAsia QZ8501 Buka Bobroknya Manajemen Penerbangan Indonesia.

[Online]

Available at:

http://nasional.kompas.com/read/2015/01/06/07260031/Kecelakaan.AirAsia .QZ8501.Buka.Bobroknya.Manajemen.Penerbangan.Indonesia

Lovelock, C. \& Wirtz, J., 2011. Service Marketing People, Technology, Strategy. 7th ed.. USA: Pearson Education Inc..

Malhotra, N. K., 2010. Marketing Reasearch An Applied Orientation. 6th ed.. USA: Perason Education Inc..

Maranda, S., 2014. Rute AirAsia QZ8501Dipenuhi Awan Comulonimbus. [Online]

Available at: https://bisnis.tempo.co/read/news/2014/12/28/090631412/ruteairasia-qz8501dipenuhi-awan-comulonimbus

Mujiraharja, H., 2014. Pesawat AirAsia Hilang Bisa Disebabkan Faktor Cuaca. [Online]

Available at:

http://news.okezone.com/read/2014/12/29/18/1084984/pesawat-airasiahilang-bisa-disebabkan-faktor-cuaca 
Nissalke, J. \& E., T., n.d. The Air Transportation In The Century 21th. [Online] Available at: http://www.eolss.net/sample-chapters/c15/E1-32-08-04.pdf

Pi, W.-P. \& Huang, H.-H., 2014. Effects of promotion on relationship quality and customer loyalty in the airline industry: The relationship marketing approach. African Journal of Business Management Vol.5 (11), 4 June , p. 4413.

Prasetio, W. \& Keni, 2014. Pengaruh Service Quality, Trust dan Corporate Image Terhadap Customer Loyalty: Customer Satisfaction Sebagai Variabel Mediator. Jurnal Seminar Nasional Kewirausahaan dan Inovasi Bisnis IV Universitas Tarumanegara, p. 306.

Sanusi, 2011. Metodologi Penelitian Bisnis. Jakarta: Salemba Empat.

Sanusi, 2015. Presdir AirAsia Akui Jumlah Penumpang Turun Akibat Tragedi QZ8501.

[Online]

Available at: http://www.tribunnews.com/bisnis/2015/01/27/presdir-airasiaakui-jumlah-penumpang-turun-akibat-tragedi-qz8501

Schiffman, L. G. \& Kanuk, L. L., 2010. Consumer Behaviour. 10th ed.. USA: Pearson Education Inc.. 